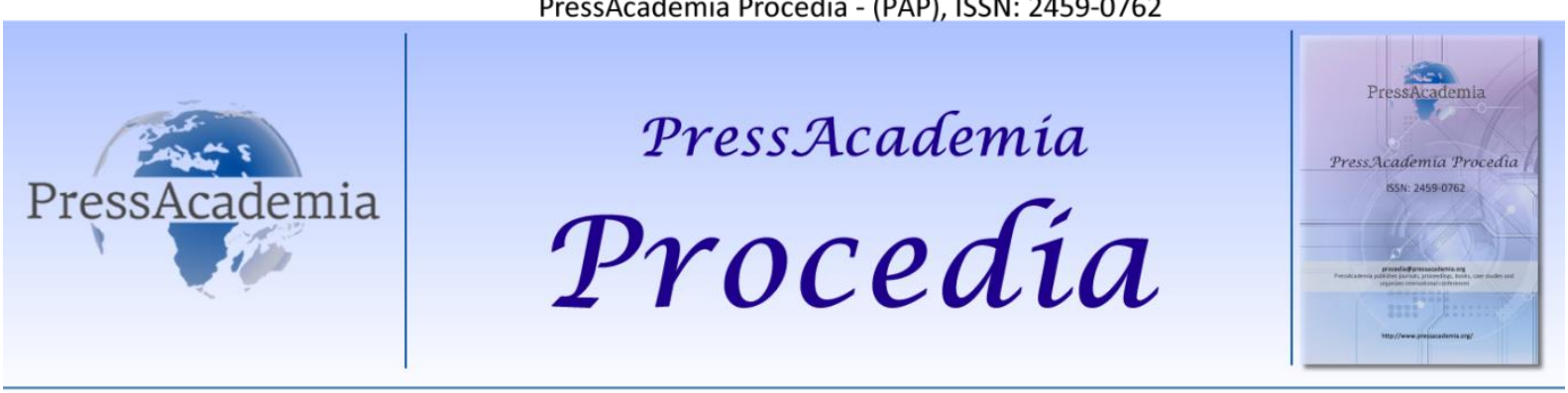

2nd World Conference on Technology, Innovation and Entrepreneurship

May 12-14, 2017, Istanbul, Turkey. Edited by Sefer Şener

\title{
FROM IDEATION TOWARDS INNOVATION: PILLARS OF FRONT-END IN NEW PRODUCT DEVELOPMENT
}

\author{
DOI: 10.17261/Pressacademia.2017.574 \\ PAP-WCTIE-V.5-2017(12)-p.71-79 \\ Onur Emre Kurt ${ }^{1}$, Caglar Ucler ${ }^{2}$, Ozalp Vayvay ${ }^{3}$ \\ ${ }^{1}$ Marmara University, onurkurt7529@gmail.com \\ ${ }^{2}$ Ozyegin University, caglar.ucler@ozyegin.edu.tr \\ ${ }^{3}$ Marmara University, ozalp@marmara.edu.tr
}

\begin{abstract}
Companies need to deliver innovative new products in order to compete in the global market successfully. Customer preferences as well technologies are highly dynamic that continuous ideation is required in the fuzzy Front End of product development, where suitable ideas have to be selected to initiate object innovation. The fuzzy Front End is mainly unorganized in companies, and there is a lack of a consistent taxonomy in the literature covering all aspects in the fuzzy Front End for successful product innovation. Consequently a model describing the pillars of the fuzzy Front End with respect to object innovation is synthesized here based on evidence from the industry supported by a systematic literature review, which shall support practitioners and researchers in the successful evaluation of innovation ideas.
\end{abstract}

Keywords: Innovation, new product development, front end, fuzzy front end.

\section{INTRODUCTION}

Companies can reach distant markets in the global business environment; however, this also elaborates the level of competition. In addition, companies need to update their product portfolios to cope with the changing consumer preferences. Therefore change and continuous development are fundamental for companies, which is leading to innovation (lyer et al. 2006), the widely accepted paradigm securing a growing market share (Gronlund et al., 2010; Bear, 2006; Andrew et al., 2010). Innovation is the introduction of something new; a new idea, method, or device: novelty (Innovation, 2017). The pragmatic as well the academic usage of innovation implies the generation of value to capture surplus (Jacobides et al., 2006). It delivers a competitive advantage in product/ service offerings (Tidd et al., 2005). Innovation shall be viewed as an end-to-end process within a value chain in interaction with resources and the environment (Hansen and Birkinshaw, 2007). Nagji and Tuff (2012) extended this concept by stating that smart firms use "total innovation" instead of depending on their future to collection of ad hoc efforts and apply a systematic approach. Thus innovative organizations are different in "strategy and vision, leadership, culture, processes, and physical work environment" (Stamm, 2003). According to OECD (2005) there are two main typologies, subject and object innovation. While subject innovation is focusing on business processes, object innovation focuses on new products/services. According the degree of the novelty, it is also designated incremental and radical innovation for minor, incremental improvements to radical changes (Tidd et al., 2005).

Koen (2004) described innovative product development process as composed of 3 phases; (i) Front End (FE), (ii) New Product Development (NPD) and (iii) Commercialization. Product innovation initiates from FE phase of NPD process, which covers idea generation and idea selection. FE covers the activities that precede structural New Product and Process Development (Koen et al., 2001), where project- /product definition is made (Achiche et al., 2013). According to Jou et al. (2016), FE is very important for the success of innovation projects, since the project is selected and then its quality, costs and schedule are defined. Sandmeier et al. (2004) implied that almost two thirds of the total cost of new product development is spent in FE phase of innovation process. Hirunyawipada et al. (2015) indicated further that when the idea is not understood deeply, lead time and cost are increased as a result of unnecessary iterations between FE and NPD phases. 
The solution of design problems in NDP or commercialization phases cost much more time and money then in the FE (Thomke and Fujimoto, 2000).

Despite its importance, FE is less researched than other phases of product development. On the top of it, FE is fuzzy (Smith and Reinertsen, 1991). Fuzziness is simply the uncertainty. FE has fuzziness sources inborn, such as changing customer requirements or available technology for the time being. Zhang and Doll (2001) also indicated in (2001) the nature of competition and changing technology in this fuzzy set, and studied the consequences of fuzziness as well: the product is not perfectly defined. This is referred as the Fuzzy Front End (FFE) in the literature. According to Brem and Voigt (2009) consequently the FFE includes unknowable and uncontrollable factors. In addition to that, the FFE has generally an unorganized structure in companies. At this point, Koen et al. (2004) introduced "front end innovation" term instead of using "fuzzy front end" term, and created a framework for FE and called this framework as New Concept Development (NCD) model.

However; while only a few researchers are studying F-/FE, even less deal with the structure of it. Although importance of FE in product innovation is known, research about how to resolve the complexity in FE is limited. There is also a lack of a consistent taxonomy in the literature covering all aspects of the fuzzy extend in the FE. The selection of ideas is a vitally important, which needs a structured approach. Consequently FFE, selection criteria and best practices for the selection of NPD ideas have to be looked at in detail that related dimensions have to be isolated, which constitute the pillars of the FFE with respect to object innovation as introduced next.

\section{REVIEW OF FRONT END METHODOLOGIES FOR INNOVATION}

One might think that unstructured FE could avoid loss of innovation project ideas because of the formalization killing the creativity. However, CEN/TS (2013) explained that structured FE is an enabler of the innovation stream delivering a continuous basis for innovation projects. In companies, generally, expert knowledge and judgment are used in FE phase for decision making purpose because of fuzziness of this phase. If FE is not structured, especially idea evaluation capability of the company will depend on individuals and would not be consistent in long term. Innovation is a process itself and must be implemented throughout the organization. Morris (2011) described the internal innovation process as a systematic process, involving strategic thinking, portfolio management and research to internalize explicit and tacit knowledge. Therefore strategy, portfolio management, R\&D, sales and marketing enable continuous growth, driven by the generation and selection of quality ideas in the FE. Consequently the FE tasks do cover product strategy formulation, opportunity identification, idea generation, product definition, product planning and reviews (Murphy and Kumar, 1997). Koen et al. (2001) classified this as opportunity identification/analysis, idea genesis/selection and concept/technology development. Deppe et al. (2002) divided FE into four stages as preparation for the idea generation, idea generation, idea screening and evaluation and the first concept, by designating the first concept as the beginning of the NPD. The FE model of Sandmeier et al. (2004) include market and technology opportunities phase, product and business ideas phase, and draft concept of product and business plan phase. The management of the project portfolio is important rather than the management of a single project for competitive advantage, and the ideation portfolio management in FE and project success do impact each other (Heising, 2012; Kock et al., 2015).

The first step in the FE process is the ideation. It is the generation, gathering, and assessing of ideas within a collaborative network. Only ideas with a high potential shall be selected for innovation success. According to Stevanovic et al. (2015) companies generally carry out the decision by using ad hoc or intuitively. However a managed and systematic approach is needed for game changing new product ideas (Cooper and Edgett, 2008), but the idea management processes are not generally managed in an organized and systematic way (Stevanovic et al., 2016). Successful ideas for NPD contain three dimensions which are novelty for customer, usefulness for customer and usefulness for companies (Hirunyawipada et al., 2015). There are two main approaches to structure the FE: the New Concept Development (NCD) model (Koen et al., 2001; Koen, 2004) further fuzzified by Achiche et al. (2013) and the Stage-Gate Model (Cooper and Edgett, 2008). The research of Koen et al. (2001) revealed that organizational attributes including senior management involvement, vision, strategy, resources and culture are the most important factors for FE performance. In the Stage-Gate model (see Figure 1) ideas are simply put through a funnel with gates after certain stages letting only successful ideas pass the designated gates. However, the requirements for the gates are not defined and kept as company specific (Riel et al., 2013). These models both apply subject innovation to reach object innovation, and consequently innovation management is applied therewith. 
Figure 1: Innovation Management Model (Microsoft, 2013)

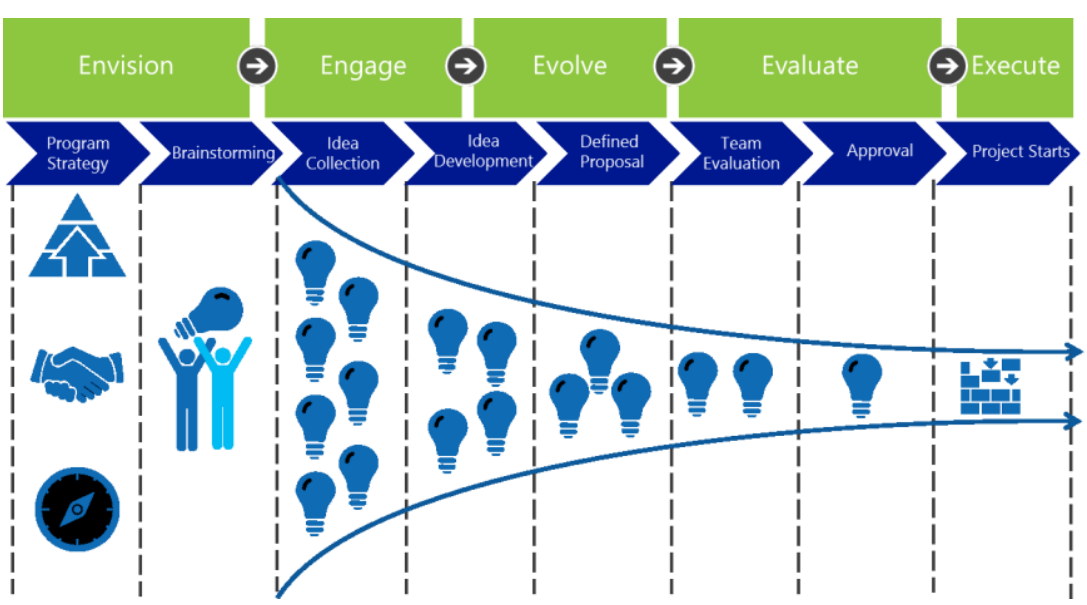

To isolate requirements the FE elements have to be understood. Chamakiotis et al. (2016) tried to isolate unique characteristics of virtual project teams with respect to collaboration in the FFE. Jou and Yuan (2016) proposed a novel method, combination of Crawford and Di Bendetto's model and Cooper's model to support the decision making in FE, and with this method they divided FE phase into four stages which are; market exploration and technology forecasting, idea generation and segmentation, portfolio analysis, and technology road mapping. Gronlund et al. (2010) proposed to combine the open innovation activities and Stage-Gate Model and called it Open Stage-Gate Model, to enable externalization. Ahmed-Kristensen and Daalhuizen (2015) proposed that the integrated usage of agile and stage-gate models as well. Sommer et al (2015) created a hybrid model, a combination of Stage-Gate and Agile Models, but only initial idea development was covered. All in one there is research indicating the importance of ideation and idea selection in the $\mathrm{FE}$. Some tools and techniques for the selection of these ideas are introduced embedded in methodologies, but there is no generalized taxonomy classifying/clustering the required aspects, which have to be respected during the idea selection process. Available literature represents a wide spread around several methodologies, but is not structured. Consequently, to remedy the complexity a harmonization shall be applied in order to deliver a set of important aspects to be respected in the FE to achieve a potential innovation outcome. In other words; the pillars of FE in NPD are to be isolated. There is enough evidence and data in the literature, which has to be synthesized to a model as discussed next.

\section{DATA AND METHODOLOGY}

This study originated from the need to select correct ideas for the innovation stream. Thus the main objective of this paper is to quantify associated dimensions affecting on the innovation output. Therefore a systematic literature review has been accomplished by using key words as [innovation; fuzzy front end; idea selection; new product development] in scientific databases including but not limited to EBSCO, Scopus and WOS Resources. This literature review ranges from surveys to papers and dissertations. A total of 58 papers, 1 graduate thesis, 6 books and 1 survey have been considered as relevant based on the evidence from industrial consulting expertise of the authors. Data gathered thereof is used to synthesize a model describing the pillars of fuzzy front-end of NPD.

\section{FINDINGS AND DISCUSSIONS}

Innovation ideas shall be collected frequently, evaluated and then executed (Stamm, 2003). More generally such ideas are to be bred, evolved and finally selected in FE phase, which consequently shall go through NPD to become an innovation output via successful commercialization. Consequently FE shall respect during concurrent ideation and evaluation all aspects of the product life cycle to avoid costly iterations. However; limited research is available for FE, and there is a gap in the literature for models' selection criteria. Despite its criticality, the idea selection phase generally depends on the area experts' subjective assessments or decisions according to their knowledge (Bear, 2006). While subjective assessment can lead towards failure; objective assessment can lead to unbiased judgement and create more opportunities. Scholars proposed to structure innovative NPD by using range from lean, agile models etc. alone to in combination of these models with the NCD and Stage-Gate models. Furthermore, idea selection is generally investigated under idealization, project portfolio management, inter-firm collaboration, inter-personnel relationship, open innovation, Agile/ Stage Gate Hybrid methods; however it is generally mentioned as a word. Barely some researches investigate selection process alone. There is no generalized taxonomy with respect to the classification of required aspects for idea selection process. Moreover, despite available methodologies in the literature, the structuration of ideation and idea selection were found to be a weak link in 
the innovation chain. In order to remedy the complexity of $\mathrm{FE}$, mainly because of ideation, pillars of $\mathrm{FE}$ are isolated and a model in which these respected pillars synthesized is applied to secure harmonization in the FE phase. In this study, Cooper's Stage-Gate Model was selected as a structure or backbone. Thus subject innovation was applied to reach the object innovation by ideas driven through gates, when meeting the criteria supported by the pillars. Consequently instead of the idea funnel approach, which is widely used in the literature, an evaluation tunnel is described (see Figure 2), where the respected pillars are supporting the idea evaluation model.

Figure 2: Pillars of the Innovative Idea Evaluation Process

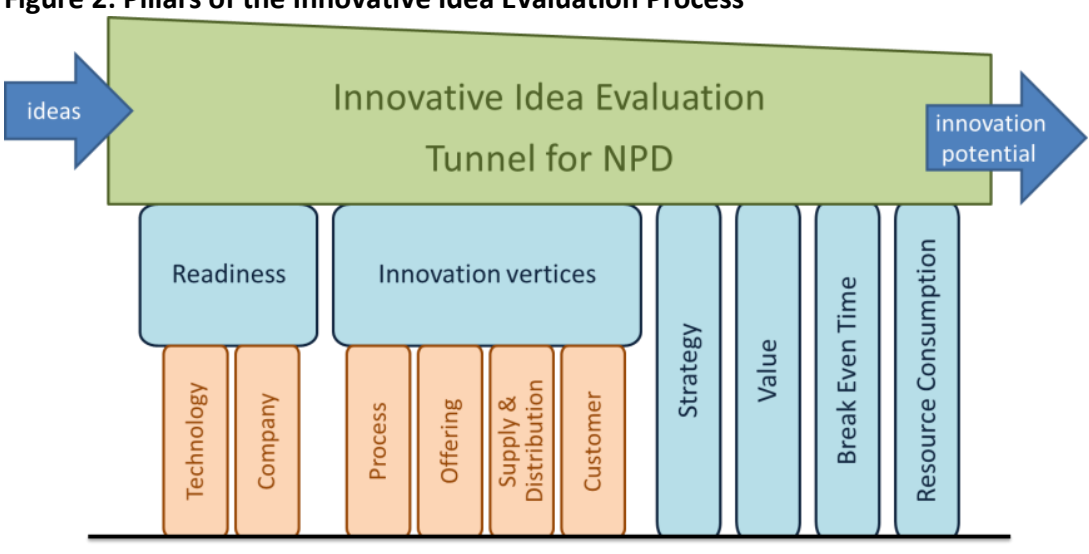

This has a specific meaning. While during the funnel approach the ideas are simply passing through the funnel, or are eliminated, in this model the ideas have to be driven through the evaluation tunnel, i.e. they have to be further evolved. Ideas with correct justifications, but wrong development direction are not simply dropped out. They are developed to achieve successful innovation. This is an extension of the model of Stevanovic et al. (2015), by which idea efficacy of innovation was evaluated by means of technical, customer, market, financial and social attributes. According to preliminary research, pillars of the idea evaluation were consolidated to six groups as (i) Readiness, (ii) Innovation Vertices, (iii) Strategy, (iv) Value, (v) Break Even Time and (vi) Resource Consumption, which will be looked at in detail next. An idea might be the brightest, but cannot be converted to innovation successfully, when the product realization is not possible due to missing technology or capabilities, i.e. it shall be determined whether the innovation idea unveils a fit with competencies (Salomo et al., 2007). Thus maybe the most important pillar is the Readiness, which consequently covers Technology and Company sub-pillars. These sub-pillars have an interaction with each other. Tidd et al (2005) indicated that when technology interacts with both the market and the company, technology related innovation projects can be achieved. The competitiveness of especially high tech companies shall and can be enhanced by successful management of technology (Kropsu et al., 2009). Therefore peripheral vision, disruptive technologies, patent mapping and idea capture internally are supporting innovation (Cooper and Edgett, 2008). In order to target and reach innovation, the nature of the idea has to be understood thoroughly. It might be that there are no breakthrough ideas, but selected ideas shall support innovation in one or another way. Tsekouras et al. indicated in (2014) four vectors as offering, process, distribution, and customer, which were also mentioned by Sawhney (2006). In consequence, the Innovation Vertices were selected as Process, Offering, Supply \& Distribution and Customer, wherefore the innovation contribution shall be questioned during the idea evaluation as explained further below.

On the one hand, innovative organizations differ in their Processes (Stamm, 2003), which describe how companies are working (Cronemyr and Danielsson, 2013) by defining activities with inputs and outputs for specific goals (Cao et al., 2013). Koen et al. (2001) indicated that creating more innovation starts with organizational attributes rather than team performance, opportunity identification or ideation. Problems arising during product realization shall leverage the redesign of processes (Tenner and DeToro, 1996). Likewise the preventive reengineering of processes by utilizing new approaches or technologies also leads to subject, i.e. process innovation (Tidd et al., 2005; Eliens, 2015; OECD, 2005). This is tightly related to knowledge management (Cao et al., 2013). Eliens (2015) indicated that process and distribution innovation as in (OECD, 2005) are not enough researched in literature. Considering that innovation can be achieved by the iteration and circulation of shared knowledge (Nonaka et al., 2008) and that process innovation involves knowledge management, the importance of the process pillar of innovation is further underlined. On the other hand, the object innovation is focused on in the Offering sub-pillar. Here the offering shall be evaluated with respect to its contribution to the object innovation. Both, products and services are covered in there (CEN/TS, 2013; Tsekouras et al., 2014). The way how the offering is organized, as well the products/services themselves are the focal point of this sub-pillar. The organization of the offering can be e.g. platform type, where common architecture of design is done and different types of product are developed on this common architecture (Koen, 2004). However, when transforming the voice of customer (VOC), the products might become 
standardized and the contribution to innovation might be reduced. Thus market research has to be done continuously (Stamm, 2003). Therefore the ideation shall be capable to look beyond the market of today and shall bring a strategic insight as well, by tracking the change today. Nevertheless Kock et al. implied in (2016) that ideation is interdepended from market environment turbulence. Consequently short time trends shall not sway the evaluation, but riskiness, portfolio size and interdepended projects have to be examined under this pillar by applying consistent portfolio management (Morris, 2011), to evaluate ideas with respect to their contribution to innovation potential as products.

The product realization is accomplished within integrated supply chains to deliver competitive advantage (Ursino, 2015), where exchange of tacit knowledge and mutual knowledge generation may not be well-preserved, which are prerequisites of innovation (Casanueva et al., 2013). However; if object innovation is supported by concrete not only internal but also external linkages, value created by can be further increased. This dilemma is described in the literature as open innovation (Chesbrough, 2006) in the collaborative virtual product realization environment (Ucler and Kristensen, 2016). Consequently this pillar is simply named here as the Supply \& Distribution in a generic manner, emphasizing that supply and distribution do contribute to the Innovation network (Tidd et al., 2005). Fuzziness can be decreased by supplier integrated FE (Wovak et al., 2016), where iterative learning cycles among integrated product development stakeholders increase the efficiency and effectiveness of the FE (Sandmeier et al., 2004). Temporary virtual project teams may have unique characteristics over FE activities (Chamakiotis et al., 2016), thus the model shall be kept as simple as possible in a collaborative and lean manner (Tuli and Shankar, 2015). Moreover, exporting and importing know-how may be inter-organizational as in open innovation, but also across various departments. Thus the internal linkages in an organization are also important in innovation (Tidd et al., 2005; Cornetto et al., 2016), where the balance between inter-firm and intra-firm structure types in FE phase should be managed properly to succeed in the market (Jörgensen et al., 2011). Innovation can be delivered by how supply and distribution is made (Tsekouras et al., 2014). Furthermore partners, vendors, external scientific/ technical communities, external finished product designs and external ideas can contribute to the open innovation (Cooper and Edgett, 2008). Thus importing external know-how and exporting internal know-how reduce cost and development (Gronlund, 2010) for the benefit of the company and the customer, which shall be evaluated here.

One aim of innovation is creating differentiated customer experience or a new clientele that Customer is selected as another sub-pillar. If early involvement of the customer is gained, product type or service needs can be understood in the early phases in the FE (Khurana and Rosendhal, 1998; Eliens, 2015). Stamm studied in (2003) the confliction between customer preference and the preference to be offered, furthermore, concluded that misinterpretations can be occurred while transforming the VOC. Moreover Cooper and Edgett (2008) include the VOC as an important idea source for innovation. But the customer vertex includes much more than the integration of the customer experience in the FE. According to Tsekouras et al. (2014) the customer as in the fourth vector of business innovation does represent new value capture through new revenue streams within new segments as well. So innovation ideas have also to be questioned with respect to new customers and the revenue stream in short term and long term.

Strategy is a key driver for product innovation (Stevanovic et al., 2016). Morris implied in (2011) that strategy and innovation form each other. Eliens (2015) and Khurana and Rosendhal (1998) indicated that strategy pillar implies the coherence between product innovation project and firm's business strategy, where internal and external environment shall be respected (Tidd et al., 2005). First the innovation strategy of the organization shall be defined (Cassiman and Veugelers, 2006) and then the ideas shall be selected according to the coverage of their business plans to the corporate strategy (Salomo et al., 2007). All strategies of the company shall be covered by the selected ideas thus the portfolio management is vitally important. Kock et al. (2015) studied the effects of ideation portfolio management on FE success, and created a research framework in which ideation portfolio management is divided into three elements which are ideation strategy, process formulization and creative encouragement, concluding that there are significant effects between these elements regarding front end success and eventually project portfolio success.

Today "high-level science and engineering are no more important than the ability to use them in mid- and ground-level innovations" (Bhide, 2009). Within the Value vertex the innovation idea shall be tested for main value drivers (Salomo et al., 2007). Therefore the practical application and the value generation shall be focused on, not how good the idea is. Especially added value can be achieved easily by incremental innovation, while other innovation types might generate totally new horizons, but imply risks. Value creation can be in different areas such as by product innovation or by business model innovation (Bhidé, A. 2009; Amit and Zott, 2012). Jacobides et al. (2006) implied that innovation value capture surplus. Hansen and Birkinshaw, (2007) studies the innovation value chain in interaction, and defined the innovation value chain as idea generation, conversion and the diffusion. Sometimes the users value of IT innovations cannot be captured with traditional accounting (Grant et al., 2013) that Porter's value chain analysis for differentiation can be used for innovation assessment as well (Ucler and Gok, 2015).

The assessment for the Break Even Time is a very important consideration. Easy to realize innovation with an early return may be preferred to increase innovation volume. Furthermore the appropriate product introduction time within the 
innovation portfolio and thus the schedule can be determined therewith (Calantone et al., 2014; Palmberg 2006). Park et al. (2016) studied the break even time analysis in NPD, and concluded that depending on businesses' cost structure and innovation speed, there is a difference in break even time of industries. Nevertheless companies shall benchmark in their segments and evaluate business cases of innovation ideas accordingly. Finally the Resource Consumption is the last important vertex. NPD projects for innovation might require many resources individually, but collectively they can consume a large amount of resources, thus a balanced portfolio management is a must (Cooper, 2003). The allocation can be adjusted (Loch and Kavadias, 2002) to have a spread over certain projects, but shall not jeopardize existing value streams. The sustainability context may be included there by sustainable innovation as well (Wever and Boks, 2007; Dewulf, 2013), but shall be better included throughout the whole evaluation process.

All in one these pillars span the solution space of the questioning towards innovation. Instead of using business specific evaluation pillars, generic idea evaluation pillars are generated to provide a general overview to the problem. These pillars might have weights associated, depending on the strategic objectives of the organization. Moreover depending on the business type minor adjustments can be done to increase the effectiveness of the innovation project, but the delivered taxonomy based on these pillars does deliver a robust evaluation respecting all aspects.

\section{CONCLUSION}

Although the importance of FE in product innovation is known, research about solving the complexity of FE is in progress. Moreover the fuzziness of the $\mathrm{FE}$ is increasing this complexity via rapidly changing variables in market conditions, technology and customer requirements. Nevertheless; a product has to successfully address the requirements by transforming technology under available market constraints. This is not an easy task; especially it is not easy to foresee the success in the FE phase. On the top of this, companies have to innovate and deliver added value to capture surplus. This automatically implies that new technologies are adopted and new ideas are transformed into products. This builds up the unknown further and the question remains open, which ideas are the best candidates for NPD, i.e. which ideas do provide the best innovation potential, but do streamline with the organizations' strategy and capabilities. Ideation is the exploratory part of FE, where NPD ideas are generated and then evaluated. The evaluated ideas, products in spe, play an indispensable role in the success of the company in the market. When the idea generation relies on persons, there is no collaboration. The outcome of such an unstructured approach is arbitrary evaluation, not complying with the innovation goals of the company. Furthermore the lack of a system for ideation, as well for evaluation and tracking does risk the continuity of the innovation. As a result the consequent selection after ideation in FFE is focused on in this study, in order to harmonize the literature and provide a model synthesized by the aspects of selection, which have to be respected in the FFE of NPD.

The New Concept Development Model and the Stage-Gate Model are popular for structured ideation and consequent evaluation throughout NPD, allowing a consistent flow of ideas through a funnel, where innovation contributors can be selected. These can be converted then into new products. In order to eliminate subjective assessments and especially to enable a multi-dimensional approach for the evaluation, the pillars of the FE were isolated, which have to be respected during evaluations. Criteria from the literature were consolidated to six groups of (i) readiness, (ii) innovation vertices, (iii) strategy, (iv) value, (v) break-even time, and (vi) resource consumption, which are proposed to be used in combination with a modified Stage-Gate Model, where ideas are driven that their evolvement is supported as well. Thereof the generic idea evaluation pillars do not depend on the nature of the business case. When after ideation these pillars are respected in the evaluation, the structured coverage eases innovation outcome by streamlining ideas, strategy and capabilities. The FE is inborn fuzzy because of the given change, but this objective, structured approach leads the way to manage the fuzziness as well.

This work contributes to the literature first by reviewing and merging FFE and idea selection related innovation literature and practices, which were found to be unorganized with a divergent spread. Then taxonomy is delivered within. Thus the practical implication is that NPD and innovation professionals can use this delivered model to cover all required aspects in their evaluations. Moreover, to attain continuous innovation, companies need to have a quality idea evaluation process, which basics are supported herewith, since this work combines many sources for idea evaluation. This work is of course of general nature and despite guiding the practical implementation it is reflecting a research in progress. Thus a robust model utilizing these pillars will be constituted within future research, minimizing the intrapersonal interactions by guiding the evaluators.

\section{ACKNOWLEDGEMENT}

The authors would like to thank to the Unit of Scientific Research Projects of Marmara University (BAPKO) for supporting this research numbered as FEN-D-250608-0182. 


\section{REFERENCES}

Achiche S., Appio F.P., McAloone T.C., and Minin A.D. (2013), "Fuzzy decision support for tools selection in the core front end activities of new product development", Research in Engineering Design, vol.24, iss.1, pp.1-18.

Ahmed-Kristensen S. and Daalhuizen J. (2015), "Pioneering the combined use of agile and stage-gate models in new product development: cases from the manufacturing industry", in proceedings of the $22^{\text {nd }}$ Innovation \& Product Development Management Conference. Copenhagen, Denmark.

Amit R., Zott C., (2012) “Creating Value Through Business Model Innovation”, MIT Sloan Management Review, Spring 2012, vol.53, no.3

Andrew J.P., Manget J., Michael D.C., Taylor A., and Zblit H. (2010), "A return to prominence - and the Emergence of a New World Order", April 2010, The Boston Consulting Group.

Bear, D.J. (2006), “The Quest for Innovation: A Global Study of Innovation Management, 2006-2016”, American Management Association, [online] http://www.amanet.org/images/hri_innovation.pdf

Bhidé, A. (2009), "Where innovation creates value", McKinsey Quarterly, Vol. February 2009, [online] http://www.mckinsey.com/businessfunctions/strategy-and-corporate-finance/our-insights/where-innovation-creates-value

Brem A. and Voigt K.I. (2009), "Integration of market pull and technology push in the corporate front end and innovation management: Insights from the German software industry", Technovation, vol.29, iss.5, pp. 351-367.

Calantone, R. J., Randhawa, P. and Voorhees, C. M. (2014), "Breakeven Time on New Product Launches: An Investigation of the Drivers and Impact on Firm Performance", Journal of Product Innovation Management, vol.31, pp.94-104.

Cao, Q., Thompson M.A. and Triche, J. (2013), "Investigating the role of business processes and knowledge management systems on performance: A multi-case study approach", International Journal of Production Research, vol.51, iss.18, pp. 5565-5575.

Casanueva, C., Castro , I. and Galán, J.L. (2013), "Informational networks and innovation in mature industrial clusters", Journal of Business Research, Vol. 66, Iss. 5, pp. 603-613.

Cassiman, B. and Veugelers, R. (2006), "In search of complementarity in innovation strategy: Internal R\&D and external knowledge acquisition", Management Science, vol.52, iss 1, pp.68-82.

CEN/TS (2013), CEN/TC 389 Innovation Management, Part 1: Innovation Management System. Technical Specification (TS) of the European Committee for Standardization (CEN), Nr. CEN/TS 16555-1:2013.

Chamakiotis, P., Boukis, A. and Panteli, N. (2016), "The fuzzy front-end of innovation in temporary virtual project teams", in Proceedings of the 10th Mediterranean Conference on Information Systems (MCIS 2016), 4-6 September, Paphos, Cyprus.

Chesbrough, H.W., Open innovation: The new imperative for creating and profiting from technology. Harvard Business Press:. Boston, Massachusetts, 2006

Cooper R. and Edgett S. (2008), "Ideation for Product Innovation: What are the best methods?", PDMA Visions Magazine, wp\#29, vol.1, iss.1, pp.12-17.

Cooper, R.G. (2003), "Your NPD portfolio may be harmful to your business's health", Research Technology Management, vol.47, iss.1, pp.31-43.

Cornetto T., Nisar A., Palacios M., Meunier-FitzHugh K., and Labadie J.G. (2016), "Organizational linkages for new product development: Implementation of innovation projects", Journal of Business Research, vol.69, pp.2093-2100.

Cronemyr, P. and Danielsson, M. (2013), "Process Management 1-2-3 - a maturity model and diagnostics tool", Total Quality Management \& Business Excellence, vol.24, iss. 7-8, pp. 933-944.

Deppe L., Kohn S., Paoletti F., and Levermann A., (2002), "The holistic view of the front end of innovation", In: Proceeding of IMTs and New Product Development Conference, Mantova, Italy, 17-18 October 2002.

Dewulf, K.R. (2013), "Sustainable product innovation: the importance of the front-end stage in the innovation process." Chapter 7 in Advances in Industrial Design Engineering, edited by DA Coelho. InTech, 2013.

Eliens L. (2015), Disentagling the fuzzy front-end: an integrative literature review. Dissertation, Faculdade de Engenharia da Universidade do Porto. [online] https://repositorio-aberto.up.pt/bitstream/10216/79627/2/35840.pdf

Grant, K., Alefantos, T., Meyer, M. \& Edgar D. (2013) “Capturing and measuring technology based service innovation - A case analysis within theory and practice", International Journal of Information Management, Vol. 33, pp. 899-905.

Gronlund J., Sjodin D.R. and Frishammar J. (2010), “Open Innovation and the Stage-Gate Process: A revised Model for New Product Development", California Management Review, vol.52, no.3, spring 2010.

Hansen, M. T. and Birkinshaw, J. (2007), "The innovation value chain”, Harvard Business Review, vol.85, iss.6, 121.

Heising W. (2012), "The integration of ideation and project portfolio management - A key factor for sustainable success", International Journal of Project Management, vol.30, iss.5, pp. 582-595. 
Hirunyawipada , T., Paswan , A.K. and Blankson, C. (2015) "Toward the development of new product ideas: asymmetric effects of team cohesion on new product ideation", Journal of Business \& Industrial Marketing, vol.30, iss.7, pp.855-866.

Innovation. [Def. 1,2] in Merriam Webster Online, Retrieved March 15, 2017, [On-line] https://www.merriamwebster.com/dictionary/innovation

lyer, R., Laplaca, P.J. and Sharma, A. (2006), "Innovation and New Product Introductions in Emerging Markets: Strategic Recommendations for the Indian market", Industrial Marketing Management, vol. 35, iss.3, pp. 373-382.

Jacobides, M. G., Knudsen, T., \& Augier, M. (2006), "Benefiting from innovation: Value creation, value appropriation and the role of industry architectures", Research Policy, vol.35, iss.8, pp. 1200-1221.

Jou G.T. and Yuan B.J.C. (2016), "Utilizing a Novel Approach at the Fuzzy Front-End of New Product Development: A Case Study in a Flexible Fabric Supercapacitor", Sustainability, vol.8, iss.8, 740.

Jörgensen J.H., Bergenholtz C., Goduscheit R.C., and Rasmussen E.S. (2011), “Managing Inter-Firm Collaboration in the Fuzzy Front-End: Structure As A Two-Edged Sword", International Journal of Innovation Management, vol.15, no.1, pp.145-163.

Khurana A. and Rosenthal S.R. (1998) "Towards holistic front ends in new product development", Journal of Product Innovation Management, vol.14, iss.2, pp. 252-269.

Kock A., Heising W., and Gemünden H.G. (2015), “How Ideation Portfolio Management Influences Front-End Success”, Journal of Product Innovation Management, vol.32, iss.4, pp.539-555.

Kock A., Heising W. and Gemünden H.G. (2016), "A contingency Approach on the Impact of Front-End Success on Project Portfolio Success", Project Management Journal, vol.47, iss.2, pp.115-129.

Koen, P. A. (2004), "The Fuzzy Front End for Incremental, Platform, and Breakthrough Products", in the PDMA Handbook of New Product Development, Second Edition (ed K. B. Kahn), John Wiley \& Sons, Inc.: Hoboken, NJ, USA.

Koen P., Ajamian G., Burkart R., Clamen A., Davidson J., D'Amore, R., Elkins C., Herald K., Incorvia M., Johnson A., Karol R., Seibert R., Slavejkov A., and Wagner K. (2001), "Providing Clarity and A Common Language to the "Fuzzy Front End", Research-Technology Management, vol.44, iss.2, pp.46-55.

Kropsu-Vehkapera, H., Haapasalo, H., Rusanen, J.-P. (2009), "Analysis of Technology Management Functions in Finnish High Tech Companies", The Open Management Journal, vol.2, pp. 1-10.

Loch, C.H. and Kavadias, S. (2002), "Dynamic portfolio selection of NPD programs using marginal returns", Management Science, vol. 48, iss.10, pp.1227-1241.

Microsoft (2013), Best Practices for Innovation: Microsoft's Innovation Management Framework. Whitepaper, Microsoft Corporation, [online] http://aka.ms/t1ufzy

Murphy, S.A. and Kumar V. (1997), "The Front End of new product development: a Canadian survey", R\&D Management, vol.27, iss.1, pp.515.

Morris, L. (2011), The innovation master plan: the CEO's guide to innovation, Innovation Academy: Walnut Creek, CA, USA, [online] http://innovationmanagement.se/wp-content/uploads/2011/08/Innovation_Master_Plan_Intro.pdf

Nagji, B. and Tuff, G. (2012), “Managing Your Innovation Portfolio”, Harvard Business Review, vol.90, iss.5, pp.66-74.

Nonaka, I., Toyama R. and Hirata, T., Managing Flow: A Process Theory of the Knowledge-Based Firm. Palgrave Macmillan: New York,2008. OECD, Oslo Manual: Guidelines for Collecting and Interpreting Innovation Data. 3rd Edition, OECD Publishing: Paris, France, 2005.

Palmberg C., (2006), "The sources and success of innovations - Determinants of commercialization and break-even times", Technovation, vol.26, iss.11, pp. 1253-1267.

Park W., Lee K., Doo S., Yoon S., (2016), "Investments for New Product Development: A Break-even Time Analysis", Engineering Management Journal, vol.28, iss.3, pp.158-167.

Riel A., Neumann M., and Tichkiewitch S. (2013), "Structuring the early fuzzy front-end to manage ideation for new product development", CIRP Annals - Manufacturing Technology, vol.62, iss.1, pp.107-110.

Salomo, S., Weise, J. and Gemünden, H.G. (2007), "NPD planning activities and innovation performance: the mediating role of process management and the moderating effect of product innovativeness", Journal of product innovation management, vol. 24, iss. 4, pp.285-302.

Sandmeier, P., Jamali, N., Kobe, C., Enkel, E., Gassmann, O., and Meier, M. (2004) “Towards a Structured and Integrative Front-End of Product Innovation", in: R\&D Management Conference (RADMA), 6 July 2004 Lisbon, Portugal.

Sawhney, M., Wolcott, R.C. and Arroniz, I. (2006), "The 12 different ways for companies to innovate", MIT Sloan Management Review, vol.47, iss. 3, p.75.

Smith, P.G. and Reinertsen, D.G., Developing Products in Half the Time. New York: Van Nostrand Reinhold, 1991. 
Stamm, B., The Innovation Wave: Meeting the Corporate Challenge, Chichester: Wiley \& Sons Ltd, 2003.

Stevanovich M., Marjanovic D. and Storga M. (2015), "A model of idea evaluation and selection for product innovation", in DS 80-8 Proceedings of the 20th International Conference on Engineering Design (ICED 15), vol.8: Innovation and Creativity, Milan, Italy, July, 27-30, 2015.

Stevanovic M., Marjanovic D. and Storga M. (2016), "Idea Management in Product Innovation - The Emprical Research Results", Technical Gazette, vol.23, iss.5, pp.1285-1294.

Sommer A.F., Hedegaard C., Dukovska-Popovska I. and Steger-Jensen K. (2015), "Improved Product Development Performance through Agile/Stage-Gate Hybrids", Research Technology Management, vol.58, iss.1, pp.34-45.

Tenner, A.R. and DeToro, I.J., Process Redesign: The Implementation Guide for Managers. Addison Wesley Longman: 1996, Harlow, UK.

Thomke S. and Fujimoto T. (2000), "The Effect of "Front-Loading" Problem-Solving on Product Development Performance", Journal of Product Innovation Management, vol.17, iss.2, pp.128-142.

Tidd, J., Bessant, J. and Pavitt, K., Managing Innovation: Integrating Technological, Market and Organizational Change. 3rd Edition, John Wiley \& Sons: 2005.

Tsekouras G., Meier C., Sutkus A. and Wolf, A. (2014), "The smE-MPOWER Business Innovation Roadmap methodology: A methodological approach for establishing in a participative way a roadmap for business innovation in SMEs", Technical Results Paper, smE-MPOWER Project of the EU (ETIS-CT-2005-023401), 12 pages, [online] www.sme-mpower.eu, CC-BY-SA.

Tuli P. and Shankar R., (2015), "Collaborative and lean new product development approach: a case study in the automotive product design", International Journal of Production Research, vol.53, iss.8, pp.2457-2471.

Ucler, C. and Gok, O., 2015, "Innovating General Aviation MRO's through IT: The Sky Aircraft Management System-SAMS", Procedia-Social and Behavioral Sciences, vol.195, pp.1503-1513.

Ucler, C. and Kristensen, K. (2016), “CONTEXT - A Novel Approach For Collaborative Virtual Product Realization and Its Disclosure Using the Business Model Canvas", in the 22 ${ }^{\text {nd }}$ ICE Conference \& 2016 IEEE Technology Management Europe Conference, Trondheim, Norway.

Ursino G. (2015), "Supply Chain Control: A Theory of Vertical Integration", Journal of Economic Analysis \& Policy, Vol. 15, No. 4, pp.18311866.

Wever, R. and Boks C. (2007), "Design for Sustainability in the Fuzzy Front End”, in Proceedings of Sustainable Innovation 07, Farnham, UK, uuid:7dd9685d-9374-4bd1-8c19-ce0582f3301a

Wovak K.D., Craighead, C.W., Ketchen, D.J., Tomas, G. and Hult, M. (2016) "Toward a "theoretical toolbox" for the supplier-enabled fuzzy front end of the new product development process", Journal of Supply Chain Management, vol.52, iss.1, pp.66-81.

Zhang Q. and Doll W.J., (2001), "The fuzzy front end and success of new product development: a causal model", European Journal of Innovation Management, vol.4, iss.2, pp. $95-112$. 